\title{
Exploring EFL Students' Preferences in Extensive Reading
}

\author{
Irena Azka Azkia \\ irenaazka@gmail.com \\ Mansyur Srisudarso \\ mansyursrisudarso@gmail.com
}

Sumarta

Litcomnet@yahoo.co.id

\section{Universitas Singaperbangsa Karawang}

\begin{abstract}
In the context of teaching language, a suitable teaching approach in the classroom affects teaching reading to language learners to be successful. The extensive reading can be used as an alternative approach to teach reading which provides many advantages for language learners specially to foster their reading skills. Many researchers have been conducted the extensive reading study, however, the majority of existing studies about the solution to teach language using extensive reading does not appear to be helpful to find students' preference from the component of extensive reading. Therefore, this present qualitative study attempts to explore students' preferences in the component of extensive reading. The findings present that the highest students' preference from the component of extensive reading is easy reading. Meanwhile, the smallest students' preference from the component of extensive reading is about teacher orientation \& guide. A future researcher is suggested to study extensive reading in other aspects besides exploring students' preference to increase the quality of next extensive reading implication to be better.
\end{abstract}

Keywords: Extensive Reading; EFL Students; Students' Preferences

\section{INTRODUCTION}

In the context of teaching language, a suitable teaching approach in the classroom affects teaching reading to language learners to be successful. The extensive reading can be used as an alternative approach to teach language which provides many advantages for language learners to foster their language skill. The eextensive reading is one of the approaches in teaching language in which the teacher provides easy material in a new language and learners read a lot of those reading material silently to obtain prevalent information from those they have been read. The process of translating words of a whole text and learning grammar or the other components are not the main focus in an extensive reading program because the learner only needs to understand the global meaning. Extensive reading is also known as pleasure reading since it provides pleasant atmosphere learners can choose reading 
material freely according to their comprehension level and reading material should be easy or not too inconvenient for them. It purposes to improve learners' confidence to read the easy text since extensive reading can bring learners' comfort zone in reading as the process of language learning. Extensive reading offers many benefits for learners, especially to their language learning development. It can influence learners to be confident readers, expand learners' vocabulary and improve learners' writing, speaking, and listening skill. It also enhances learners' positive attitudes and increases learners' motivation to study a foreign language.

Several studies of extensive reading have been conducted by many researchers. Chen et al. (2013) found that provide students to self-select material of e-book suitable to their interest in the extensive reading class increase students' reading comprehension \& vocabulary, and the student had a good reading attitude. Iwata (2020) also claimed that implementing extensive reading improves students' reading comprehension and reading fluency. Moreover, the adoption of Extensive reading in English class could facilitate students to develop their reading rate (McLean \& Rouault, 2017), vocabulary (Liu \& Zhang, 2018), and writing (Azizi et al., 2020).

In previous research, many researchers provide the solution of teaching language using extensive reading. However, the majority of existing studies about the solution to teach language using extensive reading does not appear to be helpful to find students' preference from the component of extensive reading. In fact, the principle of extensive reading is the core component to implement the extensive reading approach to teach language to be successful. Therefore, the present study attempts to explore students' preferences in the component of extensive reading. This present study is purposed to explore students' preference from the component of the extensive reading. The finding of the present study would provide the specific the students' preferences related to the 10 principles of the extensive reading during conducting the program.

\section{LITERATURE REVIEW}

\section{Extensive Reading}

Many experts have explained extensive reading into the various definition. According to Grabe and Stoller (2002:259) as cited in Kiyomi et.al (2018) assume extensive reading is a process of reading a lot of material that is within their linguistic competence. (Day \& Bamford (2002) also claim that extensive reading is reading a lot of easy material suitable to their level in the new language. It is clear in extensive reading the level of reading material should be relevant and easily suitable to students' expectations and linguistics capabilities. In addition, Alsaif \& Masrai, 2019 also explain extensive reading is reading a large of quantity text or longer reading to get a general comprehension of its meaning of what is being read instead to focus on language. Students are not reading to get understanding the aspect of its language, rather, to get information or pleasure 
Extensive reading provides many advantages in human life especially in the language teaching context since it can improve language skill including reading, speaking, and writing (Kim, 2019). Azizi et. al (2020) argue extensive reading can influence a student to have good writing ability because implementing an extensive reading approach in reading class can increase writing quality. Extensive reading can also assist students to be able fluent in reading and improve students' reading speed (Howarth \& Bollen, 2019). It also can help the student to be able to speak (Hamrayevna et al., 2019). Students have shown development of their listening ability through extensive reading ((Day, Bamford, 1982; Schieppegnell, 1984; Azizi et al., 2020).

Furthermore, extensive reading also develops not only for student's cognitive aspects but also affective aspects of learning such as student's attitude, student motivation, students' confidence, and building up good habits toward reading. According to Park (2020), extensive reading can increase positive attitudes toward learning especially in reading. It facilitates student to read what they want to read which make them enjoy in reading and read more text. Extensive reading also increases students' motivation in learning EFL (Salameh, 2017; Martina et al., 2020). Through participating in extensive reading, students also become confident readers (Asraf and Ahmad, 2003; Bell, 1998; Azizi et al., 2020). Furthermore, extensive reading is believed to build up a good habit toward reading the target language (Salameh, 2017). Extensive reading influences their interest to read inside and outside of the classroom.

Overall, many advantages of extensive reading that influence students in language learning. Not only improving language competency, but it also improves the other aspect including affective. Thus, extensive reading is considered a promising language method by many language teachers since it provides a lot of positive effects for student's language proficiency (Liu \& Zhang, 2018).

\section{The Implementation of Extensive Reading}

In the implementation of extensive reading, the 10 principles mentioned by Day and Bamford (2002) will assist teaching language using the extensive reading approach to be more successful. These 10 principles are as follow:

1) The reading material is easy. The material for language learning should be easy for a student to establish a pleasant reading. The text level for reading is suitable for students' comprehension in which it is not too easy or too difficult to facilitate reading pleasure (Alsaif \& Masrai, 2019). In addition, through easy material, students can fluency in reading since they can comprehend what is being read. Reading easy material will be easier to promote the skill of reading rate and understanding than anyone who reads difficult material (Beglar \& Hunt, 2014; Aka, 2015).

2) A variety of reading material on a wide range of topics is available. Providing a different kind of reading material encourage students' motivation in extensive 
reading. The teacher can facilitate material with English textbooks or through browsing via the internet or even lead students to find the reading material via many websites (Muchtar, 2019). The teacher needs to find interesting materials and suitable to student's comprehension levels. The reading material in extensive reading should be easy which contains familiar vocabulary and grammar suitable to students' linguistic competence (Day and Bamford, 1998; Dzulfikri \& Saukah, 2017).

3) Students choose what they want to read. Extensive reading puts students in a different role than traditional language classrooms, they can select reading material without any persuasion from the language teacher. Extensive reading provides students to decide on reading material suitable to their interests and English proficiency level (Chen et al., 2013). Free selection of reading material is primary in extensive reading.

4) Students read as much as possible. Reading amounts of quantity materials is the main characteristic in language learning through extensive reading. According to Huang (2015), Reading a large number of text forms on reading material is the major of learning extensive reading. In contrast, it is difficult to determine how much quantity of material that should be read in extensive reading. Nation and Wang (1999) as cited in Aka (2015) suggested students attempt reading a book per week. Alsaif \& Masrai (2019) also mentioned students can read many texts but the reading is not to study particular aspects of language.

5) Reading speed is usually faster than slower. Since the reading material is easy and interesting, extensive reading encourages students to be able to read fluently. It also can lead to reading speed becomes faster. Nhapulo et.al (2017) claimed an extensive reading program where students reading faster, motivates them to read more quantity in a fun way. Moreover, it is possible to guess or avoid unfamiliar vocabulary while reading since the use of a dictionary will disturb reading.

6) The purpose of reading is related to pleasure, information, and general understanding. Extensive reading is a teaching language approach that encourages the process of reading for getting enjoyment and sufficient information. Extensive reading involves pleasure reading without any additional activity of comprehension measurement and it leads the student to feel free to select their reading material (Green, 2020). The key is to promote students' reading enjoyment. Extensive reading is about building pleasure, speed, fluency through reading a large of amount text. (Waring \& Husna, 2019).

7) Reading is individual and silent. The way students reading in an extensive reading program is silent and individual. Students read the material in a silent way (Ruzin, 2019) and it conducts in students' own time if it takes outside of the classroom. Silent reading helps students to be more focused on their reading process. Silent reading maintains the reader's concentration on reading longer text (Hiebert et al., 2014, p. 8; Akbar et al., 2015).

8) Reading is its reward. Since students have their own experience in extensive reading, it does not need reading comprehension exercise after the program. The teacher must facilitate students to do follow-up activities after reading. Rather than providing comprehension questions, extensive reading encourages 
students to conduct post-reading activities including making writing report about their favorite characters on reading or about the best or worst book they have read to check students' attitude toward reading (Kim, 2019). The important is the follow-up activity should be relatable according to students' reading experience.

9) The teacher orient and guides the students. In extensive reading, the role of teacher guidance is essential since teachers can know students' respond toward what were they read. To guide the student to achieve the goals of the extensive reading program, the teacher should explain the methodology, keep track of what each student reads, and encourage them to get the value of the extensive reading program (Nurviyani, 2020). It becomes focus attention that extensive reading needs teacher orient to take responsibility of guiding students to achieve goals in the program.

10) The teacher is a role model for the reader. The teacher needs to instruct students how to be good readers in the right way. The teacher needs to show how to read effectively as a model for students to be a good readers (Ruzin, 2019). Anandari \& Iswandari (2019) also suggest teachers need to prove that s/he is also highly engaged in reading through setting the rule of "You read I read" which means that teachers need to read in when assign the students to read. The teacher should be able to promote students' belief that reading is enjoyable.

\section{The Extensive Reading in Foreign Language Among EFL Students in Indonesia}

The success of extensive reading brings language teachers to implement extensive reading into the language classroom. It is recognized to be the most successful language method not only for second language education but also for foreign language education (Salameh, 2017). In Indonesia, where English is a foreign language, many EFL teachers have been integrated extensive reading into the language classroom. For instance, Fatimah (2019) has been conducted extensive reading methods with autonomous learning for college students. She encourages students with the learning platform namely Blog to facilitate the student to do extensive reading activities. Several kinds of text are provided to read including story (comic, novel, and fable), procedure texts, news, argumentative article, biography, and journal and they should report what they have read every week on their blog after reading amounts of text. Through autonomous learning in an extensive reading classroom, it develops student's vocabulary and students' motivation in learning the language.

Permatasari et.al (2020) explore university students in Indonesia towards extensive reading using popular online platforms namely Wattpad. An extensive reading program, students can choose their reading material on Wattpad suitable to their interest. The students reveal positive perceptions towards three elements; cognitive, affective, and conative. For the cognitive element, students argue that Wattpad is a good platform to conduct extensive reading effectively since it provides several reading materials in a different genre to support reading activities. For the affective 
element, students feel enjoy and unstress during reading using Wattpad. And for conative elements, students notice that Wattpad gives the advantage to their reading habit and the ability to understanding English text. Besides, there are seven strengths of using Wattpad. Wattpad is beneficial to provide students a lot of reading material; extensive reading using Wattpad gives pleasant and interesting experience; extensive reading using Wattpad is more helpful than using printed books; extensive reading using Wattpad is more money-saving; Wattpad provides good quality content; extensive reading through Wattpad enhance students' English skills including their reading habits. However, Students sometimes get bored reading Wattpad; it causes tired eyes if use it for a long time; other notification distracts the extensive reading activity on the platform, and the platform decreases the battery power.

\section{METHOD}

\section{Design and Sample}

This study uses a qualitative approach that focuses on students' preferences in extensive reading. To explore social phenomenon about student preference in the components of extensive reading, a qualitative approach is suitable for this research. Qualitative research is defined as an approach to examining social or human problems by exploring and understanding the meaning of individuals or groups (Creswell, 2017:4). It requires collecting textual data and explain the research using interpretive analysis. This study takes place in the senior high school in Indonesia and is located in West Cikarang. It involves 36 students from eleventh-grade and EFL teachers with an age range from 15-17 years old in the academic year 2020/2021.

\section{Instrument and Procedure}

A researcher uses Interviews and as a technique to obtaining information related to the research purpose. The aim of using Interviews is to get information about students' preferences in extensive reading. Moreover, the process of collecting data is taken in July 2021. The interview is the data collection method to observe someone's experience and view using questions and answers. To answer this research question, a structured interview is used. A researcher attempts to collect specific information through formulating precise questions to student answer. Furthermore, it will conduct in a mode online through Whatsapp-Call.

\section{Data Analysis}

To analysis the data for the research, the researcher uses thematic analysis from Braun \& Clarke (2006) as cited in (Kiger \& Varpio, 2020) Six steps should be conducted appropriately;

1) Familiarizing yourself with the data 
Becoming familiar with the data set is the basic to begin all of the subsequences stages and give you meaningful guidance to the raw data. In addition, the data set on this research include an interview. Re-checking transcript data with original audio recordings for exactness will be useful in this stage.

2) Generating initial codes

A code is defined as the most basic element of the raw data that can be assessed in a valuable way regarding the phenomenon. Process of coding data can be conducted manually or with a computer program help.

3) Searching for themes

Themes should be independently meaningful and integrated into each other to form a coherent whole analytic story. There is no defined number of data to appoint a theme. Important themes provide valuable relations between data items and answer important aspects of the research question.

4) Reviewing themes

The researcher ensures that the coded data in the theme are suitable and look for all relevant codes and data extracts including in each theme. The researcher can add, merged, split, or even remove themes. the researcher also determines that all themes should be fit valuable within the data set. Revising themes and code is conducted until all data items in the coding scheme are relevant to the study, themes are reasonable and additional enhancements are not generating substantial changes.

5) Defining and naming themes

The themes' name that involved in the final report should be concise and adequately descriptive. The researcher attempts to find areas of overlap between themes, analyze the appearance of sub-themes, and make the limitation regarding the scope of each theme. The final report can present selected data extracts as key features of themes and make stories around them.

6) Producing the report/manuscript

To write the final report, the researcher should be able to not only describe codes and them but can explain obvious, brief, logical accounts related to why themes selection and description of the data are essential and proper. The researcher can combine narrative descriptions and representative data extracts such as participant's quotations to explain the data. The discussion section provides the analysis by relating themes to larger questions, discussing the implementation of findings, and inquiring about the assumptions which can build the themes. It can add a reference with literature toward selected themes to empower its analysis and positioning findings within the body of literature.

\section{FINDING AND DISCUSSION}

1) The first students' preference in extensive reading is for principle number 1 about Reading material is easy

For the component of principle 1 in extensive reading, it appears 27 findings that are mentioned by participants about their preferences related to the component of extensive reading. With those 27 findings, it shows that the 
largest number of students' preference is to principle 1 about Reading material is easy. From the interview data, 4 participants reveal the material are easy to understand, easy vocabulary, easy grammar, easy translating word, and suitable to understanding level. The students convey they feel confident while reading because easy material influences them to understand what they read in the extensive reading program. As states in (Bieri, 2015), reading material at an appropriate level pushes students interesting in reading since they understand the content of the book.

2) Second students' preference in extensive reading is for principle number 3 about learners choose what they want to read

For the component of principle 3 in extensive reading about learners choose what they want to read, it appears 20 findings. With those 20 findings, principle 3 of extensive reading is the second students' preference in the component of extensive reading. From the interview data, 4 participants reveal that they choose interesting material and consider book features while carrying out the extensive reading program. According to Day and Bamford (2002), in extensive reading, students are free to choose whatever text is suitable to their expectation to understand, to enjoy, or to learn from. The students speculate that having the freedom to choose material will be more interesting and it can motivate them during reading. One is excited simply by the fact student can choose reading material, "I can choose anything reading material. I am getting more excited to read" (IM 2, 130). The participants also display the way they choose material is based on book features including a good cover, interesting title, interesting image, and interesting synopsis of the story.

3) Third students' preference in extensive reading is for principle number 2 about A variety of reading material on a wide range of topics is available

For the component of principle 2 in extensive, it appears 13 findings that are mentioned by participants about their preferences related to $A$ variety of reading material on a wide range of topics is available. With those 13 findings, principle 2 is the third students' preference in the component of extensive reading. The teacher sets a variety of materials for students to read in an extensive reading program so they can pick any topic or genre suitable to students' interests. By providing numerous texts, helps all participants to find text since it makes them easy to choose any text they want. One says with numerous choices help her to find reading material to read, "I don't get confused looking for English reading because the teacher has helped me to provide it." (FT 2, 82). During the extensive reading program, students read both fiction and non-fiction including the novel, short stories, biography, historical story, graded readers, fable, etc. They also express that they are challenged to read the new genre that they never read.

4) Fourth students' preference in extensive reading is for principle number 5 about Reading speed is usually faster than slower 
For the component of principle 5 in extensive reading about reading speed is faster rather than slower, it appears 8 findings of students' preferences in this principle. With those 8 findings, principle 5 is the fourth students' preference in the component of extensive reading. From the interviews data, extensive reading encourages participants to be able to read faster in which saves more time while reading. It is also effective to increase reading speed and build a reading faster strategy as the 4 participants mentioned that extensive reading increases their reading speed and reading faster strategy. One expresses that she feels her reading speed increased after following an extensive reading program, "I think it helps to increase my reading speed. Because I understood the meaning of the text so that I can read it faster than usual." (RS 3, 190). According to Waringin \& Takashi (2000), as cited in (Linuwih, 2021), extensive reading gives the student a chance to read the simple text which can support them to read smoothly.

5) Fifth students' preference in extensive reading is for principle number 4 about Reading read as much as possible

For the component of principle 4 in extensive reading about learner read as much possible, it appears 7 findings. With those 7 findings, principle 4 is the fifth students' preference in the component of extensive reading. Extensive reading aims to be able to read along with reading material and still get the meaning at the first chance without the need for repeat reading (Richard \& Schmitt, 2002; Yamashita, 2002; Nhapulo et al., 2017). Participants deliver that they have read many pages of text which relative more than usual. One conveys that reading a lot makes her face new vocabulary while reading, "If I find a suitable text, I will read a lot of text. So, I can find new words too." (AL $3,180)$.

6) Sixth students' preference in extensive reading is for principle number 6 about The purpose of reading is usually related to pleasure, information, and a general understanding

For the component of principle 6 in extensive reading about the purpose of reading is usually related to pleasure, information, and general understanding, it appears 5 findings. With those 5 findings, principle 6 is the sixth students' preference in the component of extensive reading. 4 participants reveal that their reading purpose is related to reading for pleasure, reading for information, and reading for general meaning. While carrying out extensive reading, all participants want to enrich knowledge from what they have read. A participant expresses that she finds new information from the text and new reading experience during extensive reading "The text that I read also added new information and reading experience" (RI 2, 130). Extensive reading encourages students to read to get pleasure and sufficient understanding (Day, Richard, and Bamford, 2002).

7) Seventh students' preference in extensive reading is for principle number 7 about Reading is individual and silent 
For the component of principle 7 in extensive reading about reading is individual and silent, it appears 5 findings. With those 5 findings, principle 7 is the seventh students' preference in the component of extensive reading. The way reading in extensive reading is silent. Extensive reading engages participants to focus on reading longer reading materials (Hiebert et al., 2014, p. 8; Akbar et al., 2015). Participants express that silent reading influences them to be able to maintain their concentration to comprehend their reading. One mentions he has better comprehending the material through silent reading, "Since how reader read the text silently, I am more focused and it easier to find the meaning of the story." (SR1, 62).

8) Eighth students' preference in extensive reading is for principle number 8 about Reading is its reward.

For the component of principle 8 in extensive reading about reading is its reward, it appears 4 findings. With those 4 findings, principle 8 is eighth students' preference in the component of extensive reading. In extensive reading, the follow-up task is not about comprehension exercise but the task which integrates students' reading experience. Reading log can be an alternative post-reading activity in extensive reading (Diptoadi, n.d.). Reading log purposes to explore students' attitudes toward their reading and to explore students' understanding of what they have read. It helps them to remember the story that they read. One says after writing the reading log, she can more understand what she reads, "In the reading log, I was asked to retell the text that I had read in my language. It makes me know more deeply about the story."(MT2. 122). For the teacher, applying a reading log into the extensive reading program can assist to keep track of what students read.

9) Ninth students' preference in extensive reading is for principle number 10 about The teacher is role model of a reader.

For the component of principle 10 in extensive reading about the teacher is the role model of a reader, it appears 3 findings. With those 3 findings, principle 10 is the ninth students' preference of the component of extensive reading. In extensive reading, teachers become models of how to be a good reader and should be able to reflect that reading is a pleasure activity so it can motivate the student to love reading. To be appropriate to practice how to be a good read for students, the teacher attempts to adopt teacher modeling by (Anandari \& Iswandari, 2019) which apply the rule "You read, I read". It seems successful since when the teacher also reads, it motivates students to read during extensive reading. A sparticipant reveals her excitement about teacher involvement in reading, ".....It motivates me to read too because the teacher's involvement in reading means a lot to me.” (TR1, 65). It certainly encourages students in reading. It indicates that teacher modeling influence student to build a reading habit

10) The tenth of students' preference in extensive reading is for principle number 9 about The Teacher orients and guides the student. 
For the component of principle 9 in extensive reading about the teacher orients and guides the student, it appears only 1 finding. With that 1 finding, principle 9 is the tenth students' preference in the component of extensive reading. Extensive reading need teacher guidance to monitor student in the reading process and ensure them to get knowledge from the program (Nurviyani, 2020). One mentions that the teacher has guided him properly in the extensive reading program, "It's good enough since during the extensive reading program, the teacher gives clear instructions on how to read extensively." (TG 3 , 202). Teacher should need pay attention more to guide students during extensive reading since the suitable teacher guidance can bring the goal of extensive reading program can be achieved.

\section{CONCLUSION}

The current study explores students' preferences in the component of extensive reading. The participants of this study are EFL senior high school students in the eleventh class in the academic year of 2020/2021. To express their preference in the component of extensive 'reading during the program, the process of interview is conducted. The interview questions are constructed based on Day \& Bamford (2004) theories about 10 principles in extensive reading. The findings present that the highest students' preference in the component of extensive reading is easy reading material which is related to principle 1 of extensive reading. However, the smallest students' preference from the component of extensive reading is related to teacher orientation \& guide which include in principle 9. Regarding the results of the study, it will be better if researchers that are interested to conduct a research extensive reading to study more about students' preference in principle 9 related to teacher orient since it is the smallest preference in an extensive reading program in current research. Or even, the future researcher is also suggested to study extensive reading in other aspects besides exploring student' preference to implement extensive reading in future to be effective. Although this research is still far from perfect, this article can be a reference for the researcher to conduct the next research to be better.

\section{REFERENCES}

Aka, N. (2015). Although the Japanese Ministry of Education. Reading in a Foreign Language, 31(1), 1-18. http://nflrc.hawaii.edu/rfl

Akbar, R. S., Taqi, H. A., Dashti, A. A., \& Sadeq, T. M. (2015). Does e-reading enhance reading fluency? English Language Teaching, 8(5), 195-207. https://doi.org/10.5539/elt.v8n5p195

Alsaif, A., \& Masrai, A. (2019). Extensive Reading and Incidental Vocabulary Acquisition: The Case of a Predominant Language Classroom Input. International Journal of Education and Literacy Studies, 7(2), 39. https://doi.org/10.7575/aiac.ijels.v.7n.2p.39

Anandari, C. L., \& Iswandari, Y. A. (2019). Extensive reading in indonesian schools: A successful story. Teflin Journal, 30(2), 137-152. 
https://doi.org/10.15639/teflinjournal.v30i2/137-152

Azizi, M., Tkáčová, H., Pavliková, M., \& Jenisová, Z. (2020). Extensive Reading and the Writing Ability of EFL Learners: the Effect of Group Work. European Journal of Contemporary Education, 9(4), 726-739. https://doi.org/10.13187/ejced.2020.4.726

Bieri, T. E. (2015). Learner Reflections on Extensive Reading Materials.

Chen, C. N., Chen, S. C., Chen, S. H. E., \& Wey, S. C. (2013). The effects of extensive reading via e-books on tertiary level EFL students' reading attitude, reading comprehension and vocabulary. Turkish Online Journal of Educational Technology, 12(2), 303-312.

Creswell, J. W. (2017). Research design: Qualitative, quantitative, and mixed methods approaches.

Day, Richard and Bamford, J. (2002). Top Ten Principles for Teaching Extensive Reading1. Reading in a Foreign Language, 14(2), 136-141.

Diptoadi, G. ; V. L. (n.d.). STUDENTS' PERCEPTION OF EXTENSIVE READING ACTIVITY THROUGH READING LOG Gabriella 3 ; Veronica L. Diptoadi 4. 46, 201-215.

Dzulfikri, D., \& Saukah, A. (2017). Extensive Reading in Action: Voices from the Grounds. Journal of Education and Learning (EduLearn), 11(2), 111-119. https://doi.org/10.11591/edulearn.v11i2.5971

Fatimah, A. S. (2019). Portraying Learner's Autonomy in Extensive Reading Classroom. OKARA: Jurnal Bahasa Dan Sastra, 13(1), 35. https://doi.org/10.19105/ojbs.v13i1.2228

Green, C. (2020). Extensive reading and viewing as input for academic vocabulary: A large-scale vocabulary profile coverage study of students' reading and writing across multiple secondary school subjects. Lingua, 239. https://doi.org/10.1016/j.lingua.2020.102838

Hamrayevna, R. O., Rashidovna, S. M., \& Shuhrat qizi, R. R. (2019). Impact of extensive reading to develop speaking skills. International Journal on Integrated Education, 2(4), 11-13. https://doi.org/10.31149/ijie.v2i4.98

Howarth, M., \& Bollen, D. (2019). Student perception of online extensive reading platform. Procedings of Sojo University Vol. 44, 145-152.

Huang, Y. C. (2015). Why don't they do it? A study on the implementation of extensive reading in Taiwan. Cogent Education, 2(1), 1-13. https://doi.org/10.1080/2331186X.2015.1099187

Iwata, A. (2020). How Extensively Do We Need to Read to Improve EFL Reading Ability?: A Comparison of Two Different Instructional Methodologies. The Reading Matrix: An International Online Journal, 20(1), 66-83.

Kim, M. (2019). The Perceptions of Students and Teachers on the Practice of Assessment in Extensive Reading. English Teaching, 74(4), 179-203. https://doi.org/10.15858/engtea.74.4.201912.179

Kiyomi, Y., Atsuko, T., \& Kyoko, O. (2018). How Does Extensive Reading Help Japanese EFL Learners to Develop Grammatical Knowledge and Reading Fluency. Journal of Extensive Reading, 4, 1-11. https://jaltpublications.org/content/index.php/jer/article/view/117

Linuwih, E. R. (2021). The Effectiveness of Extensive Reading in Improving EFL 
Academic Writing. Journal of English Language Teaching and Linguistics, 6(1), 167-177.

Liu, J., \& Zhang, J. (2018). The Effects of Extensive Reading on English Vocabulary Learning: A Meta-analysis. English Language Teaching, 11(6), 1. https://doi.org/10.5539/elt.v11n6p1

Martina, F., Syafryadin, S., \& Utama, J. A. (2020). The Practice of Extensive Reading among EFL Learners in Tertiary Level. Yavana Bhasha: Journal of English Language Education, 3(2), 56. https://doi.org/10.25078/yb.v3i2.1712

McLean, S., \& Rouault, G. (2017). The effectiveness and efficiency of extensive reading at developing reading rates. System, 70, 92-106. https://doi.org/10.1016/j.system.2017.09.003

Nhapulo, M. A., Simon, E., \& Van Herreweghe, M. (2017). Enhancing academic reading skills through extensive reading. Southern African Linguistics and Applied Language Studies, 35(1), 17-40. https://doi.org/10.2989/16073614.2016.1267578

Nurviyani, V. (2020). Implementation of Extensive Reading Through a Digital Instructional Media. ELTIN Journal, 8, 35-41.

Park, A. Y. (2020). A comparison of the impact of extensive and intensive reading approaches on the reading attitudes of secondary EFL learners. Studies in Second Language Learning and Teaching, 10(2), 337-358. https://doi.org/10.14746/ssllt.2020.10.2.6

Permatasari, I., Wijayanto, A., \& Kristina, D. (2020). The Strengths and Weaknesses of Extensive Reading using Wattpad; Students' Perceptions. Indonesian Journal of EFL and Linguistics, 5(2), 373. https://doi.org/10.21462/ijefl.v5i2.292

Ruzin, M. (2019). Implementing Extensive Reading to Boost Students 'Reading Ability. Proceeding of 1st Conference of English Language and Literature (CELL) :Innovative Teaching of Language and Literature in Digital Era., 111.

Salameh, L. A. M. (2017). Investigating the Effect of Extensive Reading on EFL Learners' Reading Attitudes at Hail University in KSA. Journal of Education and Practice, 8(8), 7-15. http://ezproxy.lib.uconn.edu/login?url=https://search.ebscohost.com/login.as px?direct=true $\& \mathrm{db}=$ eric $\& A N=E J 1139062 \&$ site $=$ ehost-live 